\title{
A POSSIBLE NEW AUXILIARY UNIT IDENTIFICATION AT POROLISSUM?
}

\begin{abstract}
The author is reopening the file of an enigmatic tile-stamp found in the Roman fort at Porolissum and in the neighbor one at Romita. He is challenging the old proposed reading c(o)horti(s) I(primae) I(turaeorum) (milliariae) with $c(o) h$ (ortis) S(agittariorum) I(primae) (milliariae), which can be the same with cohors I milliaria sagittariorum attested by late $1^{\text {st }}$ century $\mathrm{AD}$ military diplomas in Judeea and with no later records in other provinces, or with cohors I sagittariorum milliaria first time attested at Tibiscum in Upper Dacia in AD 165. The chronology of two tile-stamps found at Porolissum in precise archaeological contexts, as well as the one from Romita is in HadrianAntoninus Pius time when the unit worked to the building of the stone buildings from the interior of the two forts, belonging to the first stone phase of the forts. As no official inscription of the unit survived, it was probably a unit brought from other province to participate to the huge effort of building the northern frontier defenses of Dacia, together with detachments of legio VII Gemina Felix, legio III Gallica, or cohors III all attested only by tile-stamps at Porolissum.
\end{abstract}

Keywords: cohors, Porolissum, tile-stamps, military diplomas, archaeology.

$\mathbf{A}$ lot of pages have been written on numerous tile-stamps found during one century of archaeological excavations at Porolissum ${ }^{1}$. The variety of types mentioning many military units which worked at a moment at Porolissum and the missing of the precise archaeological context of discovery for their majority made difficult setting them in chronological order. When an outdated research methodology is used, and the authors have preconceptions on the archaeological materials and totally ignore the known information on the places where the tile-stamps were found, most of their chronological conclusion are upside down².

There are also some situations when even the identity of an auxiliary unit is uncertain and the reading of the abbreviation used in the tile-stamp is difficult. In such cases if adding a groundless chronology, the confusion increases. It is the case of a tile-stamp found at Porolissum and in the neighbour fort from Romita in six main variants: CHS2; CH2S; CHS 2; CH2 S; CHSI 2; CHSIJZ (Fig 1; Fig. 2). Along the time many attempts of reading the abbreviation were registered. In 1944, C. Daicoviciu preferred the reading $c(o) h($ orti)s I (H)is(panorum), but not excluded also a possible $c(o) h$ (orti)s I I(turaeorum) s(agittariorum $)^{3}$. J. Szilágyi ${ }^{4}$ was the first who compared different

\footnotetext{
${ }^{1}$ Among the main contributions to the subject, see TÓTH 1978; GUDEA 1989; OPREANU 2015; OPREANU 2018.

2 PISO/DEAC 2016; PISO/MARCU 2016.

${ }^{3}$ DAICOVICIU 1941-1943, 320.

${ }^{4}$ SZILÁGYI 1946, nr. 228-231.
}

\section{Coriolan Horatiu Opreanu}

Institute of Archaeology and Art History Cluj-Napoca

choprean@yahoo.com

DOI: $10.14795 /$ j.v6i4.473

ISSN 2360 - 266X

ISSN-L 2360 - 266X 

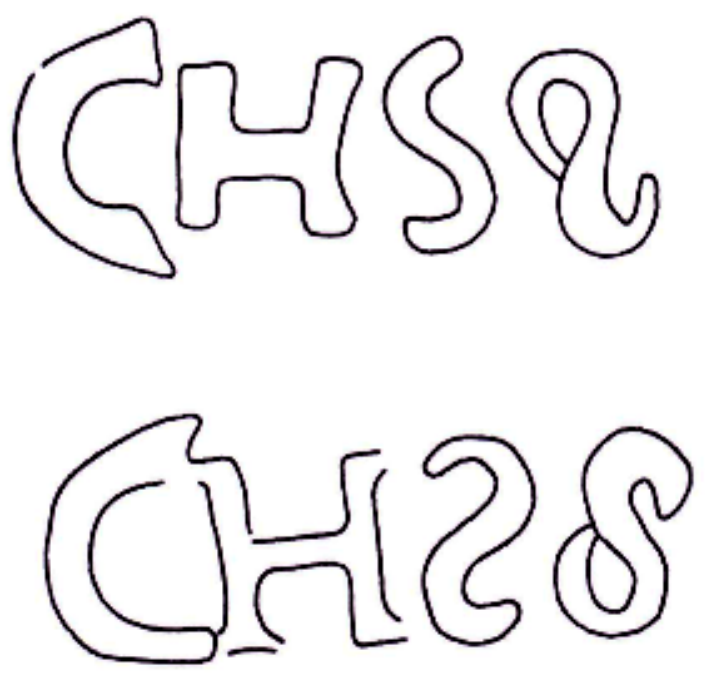
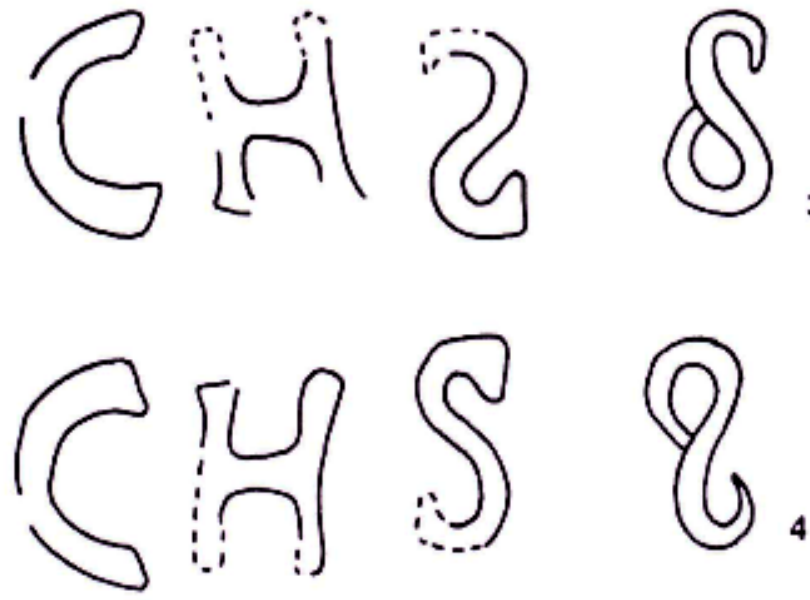

4
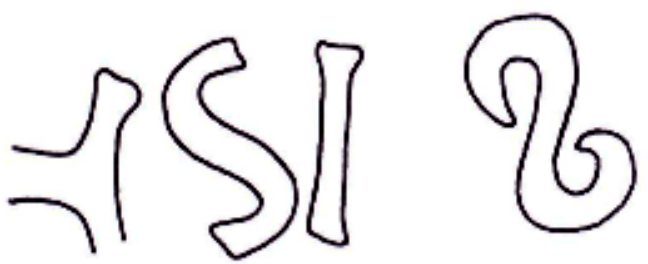

5

Fig. 1. 1-5 tile-stamps from the old research at Porolissum (after ȚENTEA 2004)

types of the tile-stamp and proposed more solutions, for each of them: $c(o) h$ (orti)s I P(almyrenorum) s(agittariorum), $c(o)$ $h$ (orti)s s(agittariorum), c(o)h(ortis) S(urorum) s(agittariorum). When offering the first solution he excluded the possibility of existing a "J" coming from I(turaeorum) and appreciated the capital letter was a turned "P". Very influent for future debate was the opinion of E. Tóth ${ }^{5}$ from 1978. He is cataloguing 9 tile-stamps discovered in A. Rádnoti's old excavation. Seven of them were found in the headquarters building and one in a tower of porta praetoria, while the ninth one was a stray find. Among the 7 stamps from principia, 2 were of type CHSIJ ${ }^{6}$ and 4 of type CHS $^{7}$, one fragmentary. That means both types were contemporary and represent the same unit

5 TÓTH 1978, 50-51.

TÓTH 1978, nr. 52; 171, Abb. 16.

TÓTH 1978, nr. 83; 84; 145; 163, Abb. 16. and the differences between the two stamps were not very important for the unit identification in antiquity. At the same time, it is obvious that the two types have the same chronology. The main new idea of E. Tóth was that the fifth letter in the type CHSIJ? was not a "P", but an "I", designed like a "J" to avoid confusion with the previous numeral "I" and that the last sign " $\mathrm{"} \mathrm{was} \mathrm{closer} \mathrm{to} \mathrm{an} \mathrm{eight} \mathrm{and} \mathrm{was}$ the abbreviation for milliaria. So he proposed the reading $c(o) h$ (orti)s I I(turaeorum sagittariorum) (milliaria). The Hungarian scholar briefly commented also the type CHS? rightly appreciated that the third letter " $\mathbf{S}$ " cannot belong to the word cohors, the most probable reading being $c(o) h(o r s)$ $S$ (agittariorum (milliaria) ${ }^{8}$. But he immediately rejected such a hypothesis, because a unit with this name was not known in the Dacian army and it didn't fit with the other tile-stamp type (CHSIJZ).

N. Gudea ${ }^{9}$ believed it was about cohors I Hispanorum Pia Fidelis. He is counting "many tile-stamps everywhere in the fort and in the town". There are 34 pieces in his catalogue ${ }^{10}$. Much interest to the theme manifested O. T,entea. He reanalyzed the tile-stamps and became convinced that the only valid solution is to identify the abbreviation with cohors I Ituraeorum milliaria ${ }^{11}$.

I. Piso and his collaborators recently catalogued all the tile-stamps from the Museums in Zalău and ClujNapoca. They found in the museum from Zalău 27 tile-stamps of the types above mentioned and other 7 in the museum from Cluj-Napoca ${ }^{13}$. From the beginning it is clearly that the authors were not confident in their option as in the twin volumes the same tile-stamps were described under two different subtitles: "Cohors I Augusta Ituraeorum?"and "Cohors I Ituraeorum (milliaria)?". The first one is for sure totally wrong as cohors I Augusta Ituraeorum is obviously another unit with tile-stamps found at Buciumi and Porolissum (COH I AVG) ${ }^{14}$ and not recorded in the military diplomas of Dacia Porolissensis but is attested in Upper Dacia in AD $124^{15}$. The main argument against this identification is the epithet Aug(usta), whose abbreviation does not exist in the stamps we are analyzing. The authors are not doubtless hanging in the balance the reading cohortis I Ituraeorum milliariae. Taking into consideration the type CHSR, they are advancing a second possible choice $c(0)$ $h$ (ortis) s(agittariorum) (milliariae) ${ }^{16}$, also considered but at the end rejected by E. Tóth ${ }^{17}$.

We think it worth taking into consideration this last suggestion. First, there is no example, at least among the tilestamps from Dacia Porolissensis, of the abbreviation $C(0)$ $H$ (orti)S. Cohors-tis was always abbreviated in the tile-stamps as $\mathbf{C}, \mathbf{C H}, \mathbf{C O H}$, or infrequently COR. It is unbelievable that from the four letters in the stamp, three to be used for the
TÓTH 1978, 50.
9 GUDEA 1989, 165-166
${ }^{10}$ GUDEA 1989, 523-524.
11 T,ENTEA 2004; ŢENTEA 2012, 55-60.
12 PISO/DEAC 2016, 240-248.
13 PISO/MARCU 2016, 165-168.
14 GUDEA 1989, 166-168; PETOLESCU 2002, 116, nr. 49: ȚENTEA 2012, 52-55.
15 AE 2010, 1837
16 PISO/DEAC 2016, 240
17 See, footnote 8. 

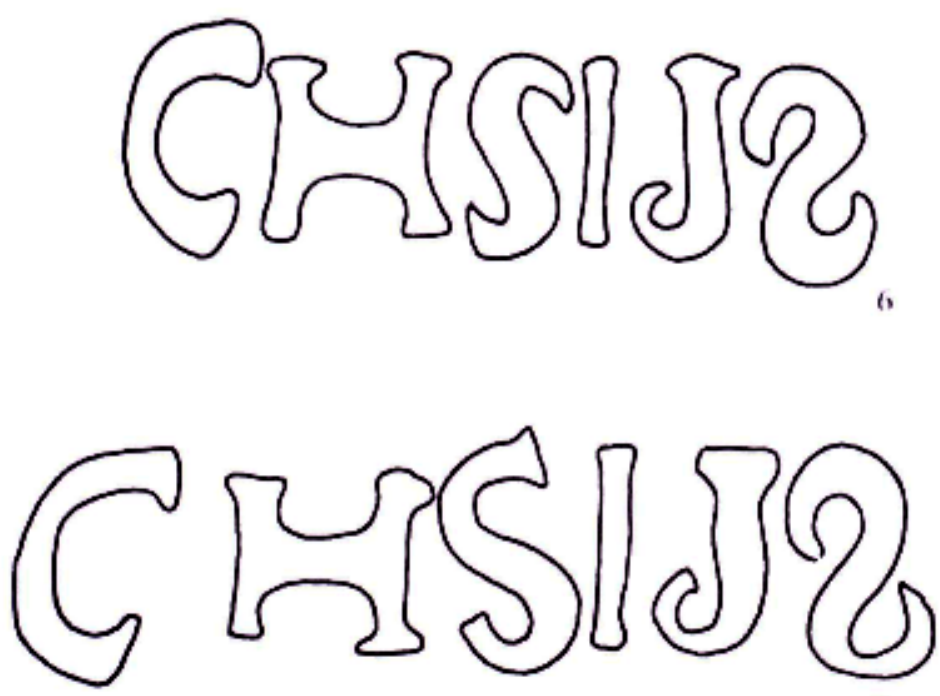

7
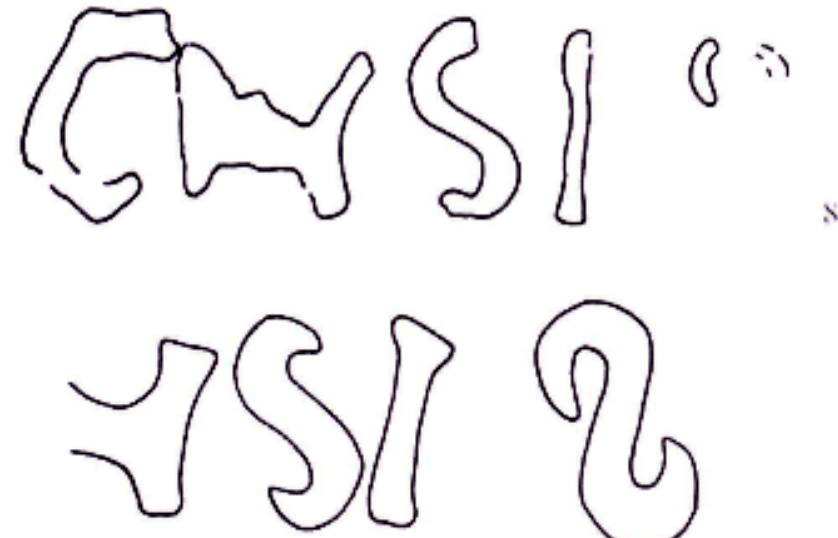

9

Fig, 2. 6-7 tile-stamps from the old research at Porolissum; 8-9 tile-stamps from the old research from the Roman baths and fort at Romita (after ȚENTEA:2004).

First the type CHSI R. A letter "I", or a numeral was added after the presumed $S$ (agittariorum). It is hard to believe it is an abbreviation from an ethnonym, the intention of stamping tiles being not reading riddles by the outside onlooker. So is more logical to be a numeral. Our proposal is the reading $c(0)$ $h$ (ortis) S(agittariorum) I (primae) (milliariae). Why is not possible to be an "I" from I(turaeorum)? Because the first letter is not enough to understand this word and because it is not plausible to think that the most important abbreviation is missing from the other four types. That is the message of the graffiti "ITV" found at Porolissum ${ }^{18}$. But the story of this tile-stamp is not finished. There is a sixth type which makes the conclusion more complicate: CHSIJ2. A sign looking like a "J" is added in the stamp, between the numeral "I" and the last sign for milliaria. It was explained by E. Tóth as a substitution for an "I" from I(turaeorum) written like a "J" avoiding in this way a confusion with the previous numeral "I". This explanation seems acceptable at the first sight. But we must be careful: if the sign is a " $\mathbf{J}$ " (which is doubtful), this letter is rarely used in Latin epigraphy. It is hard to admit that in a frontier military society, with rigid rules, such an innovation concerning the official name of the unit was possible and comprehensible. There are many examples when to avoid confusion between the numerals and letters were used more simple and efficient methods. On the other hand, the ethnonym (if existed) was not possible to be omitted from the other five types of stamps used at the same time. The position of the sign, before the sign for milliaria and the distance between the first four letters and the last two signs make possible the interpretation of the sign similar to a "J" as another abbreviated appellative of the unit, such as $p$ (editata), for example, if it is an upsidedown "P" as J. Szilágyi suggested, (or why not even

on-record word "cohors" and only one left for the identity of the auxiliary unit. It is more reasonable to believe that CH was the abbreviation for $\mathrm{C}(\mathrm{o}) \mathrm{H}$ (ortis) as in many other cases. That means that the next letter "S" is in all types of the stamp the abbreviation for the ethnical, or other word pointing out the identity of the unit. A simple "S" is hard to believe that is the beginning of an ethnonym. There are too many starting with "S" not to create confusion in antiquity. At the same time, it is interesting to emphasize that there are two types of the stamp, CH2S and $\mathbf{C H}$ 2 $\mathbf{S}$, where the first letter after $\mathbf{C H}$ is an "S" upside-down, which can be either a vertical sign for milliaria, as E. Tóth demonstrated for the last sign in all the types, "२". In this case would be not unreasonable to read $c(o) h$ (ortis) (milliariae) S(agittariorum). The only obstacle in front of this hypothesis is that the final letter, even in a correct position of an "S", looks closer to an "8", while the third one reminds of an "S" even upsidedown, a situation often recorded in other tile-stamps from Dacia. In conclusion, $c(o) h$ (ortis) S(agittariorum) (milliariae) is the only possible reading. But a final decision cannot be taken before explaining the other types of the tile-stamp. $P$ (orolissensium), as we know from well-known numerus Palmyrenorum Porolissensium). None of these last hypotheses do not close the problem.

Let us try now to find out more about the history of this unit. Previous research started from the idea that it must be identified in the abbreviated text from the tile-stamps in discussion an auxiliary cohort from the army of Dacia. That was the reason it was preferred the cohors I Ituraeorum, recorded in the military diplomas of Trajan's Dacia ${ }^{19}$. But this unit did not let any stone inscription in Dacia Porolissensis ${ }^{20}$ and is absent from the military diplomas after AD 123. Piso's appreciation ${ }^{21}$ that it was part of the army of Dacia

\footnotetext{
18 PISO/DEAC 2016, 240 ,248.

19 PETOLESCU 2002, 116, nr. 46.

20 The fragmentary inscription found walled in a barrack of the Roman fort at Buciumi (CHIRILĂ et alii 1972, 117, nr. 11) is not sure belonging to cohors I Augusta Ituraeorum, as the only survived part of the name of the unit is the numeral "I", cohors I Brittonum, cohors I Flavia Hispanorum, cohors I Hispanorum quingenaria being either attested at Buciumi in the first Trajanic phase of the barracks by bronze appliques having punched the abbreviated name of the units (GUDEA 1997, 26, Fig. 29).

${ }_{21}$ PISO/DEAC 2016, 43, 240, 241, 248; PISO/MARCU 2016, 88, 165, 166.
} 
Porolissensis during the $3^{\text {rd }}$ century is totally devoid of any scientific evidence ${ }^{22}$. Summarizing, Piso does not accept that the tile-stamps COH I AVG from Buciumi and Porolissum had any relation with cohors I Augusta Ituraeorum (which was from the beginning in the fort at Călugăreni from Upper Dacia in his opinion $)^{23}$. But the tile-stamp we are dealing with in this paper he considered belonging to cohors I Ituraeorum milliaria which would have been in the fort at Porolissum in the $3 r d$ century ${ }^{24}$.

If there are still some epigraphic querries concerning the identity of the unit recorded in the tile-stamps from Porolissum above analyzed, establishing their chronology is the duty of archaeology. Most of the 34 tile-stamps published have no precise context of discovery. By good fortune there are few found in well dated archaeological contexts. In the Roman fort at Romita during the excavations of Al. V. Matei and I. Bajusz it was discovered in section II, $m$ 11-12, at $1.60 \mathrm{~m}$ depth a fragmentary tile-stamp of type CHSI ? (Fig. 2/8) identical to another found in the bath building of the fort in 1972 (Fig. 2/9). We examined the drawing of the vertical profile of section S II/1996, trying to reconstruct the stratigraphical position of the tile-stamp. It was obvious from the beginning that at $1.60 \mathrm{~m}$ depth was one of the early layers sealed by later ones and by the final rubble of the buildings. The bottom line of the profile was named by the excavators "level of the first stone phase of the barrack". The excavation was not finished, it did not attain the wooden

\footnotetext{
${ }^{22}$ In another paper I. Piso is doing his best to find inexistent evidence for his preconceived network. He gave a new reading to an old discovered fragmentary inscription from the fort at Buciumi (see, footnote 20). Concerning its chronology, it was dated initially in Trajan's time (PETOLESCU 2002, 90, footnote 8). Later the same author considered it was from Hadrian's late reign, AD 135 (ILD, 635). Recently I. Piso has reverted to this incomprehensible fragment of inscription, even known from 1972. He challenged the old dating, proposing the same unit (cohors I Augusta), but a chronology in Gordianus III time, in AD 241, without adding any new evidence (PISO 2016, 35-39). Then he denied the inscription and the tile-stamps found at Buciumi belong to cohors I Augusta Ituraeorum, which is to be identified by the tile-stamps CPAI from the fort at Călugăreni (Mureș County). So, the unit was part of the army of Upper Dacia from the beginnings and it never belonged to the army of Dacia Porolissensis. How can be proofed this allegation? It cannot be verified, instead cohors I Augusta Ituraeorum is not recorded in the first military diploma of Upper Dacia, from 12 November 119 (RMD V, 351), being first time recorded in Dacia Superior in the diploma from AD 144 (IDR I, 14). And another detail: the inscription from the fort at Buciumi was found walled in a barrack. In Piso's windy logic we have to imagine that in AD 241 a statue was erected (where? In principia of course) for the emperor Gordianus III, by an unknown unit which stayed together (in the $3^{\text {rd }}$ century) with the cohors II Nervia Pacensis Brittonum milliaria. Later the principia and the statue were destroyed by enemy (when? in Philippus Arab time, maybe. Hard to believe as this emperor and his family got statues in the forum of the neighbor municipium Porolissensis). Later, maybe under Decius (?). Then in the period 253-260 one of the units started to rebuild the barracks, using in the walls, among others, a fragment from the former imperial monument brought from the ruins of the headquarters building? Such a scenario is impossible to be credible as in $\mathrm{AD} 251$ a statue of the empress Herennia Etruscilla was used to block a gate of the fort at Porolissum and in most of the forts all type of monuments and inscriptions were taken to desperately overbuild the defense walls (not barracks!) not high enough against the siege skills of the barbarians, while in AD 262 the catastrophic situation of Dacia reach its peak (this last realistic view belongs to I. Piso himself, see, PISO 2018, even it does not fit with his previous paper-PISO 2016).

23 We must not forget that cohors I Alpinorum attested by tile-stamps at Călugăreni and Sărățeni (IDR III/4 165) (now reinterpreted by I. Piso) is recorded among the auxiliary troops of Dacia in the military diploma from AD 114 (RMD IV, 226).

${ }^{24}$ PISO 2016, 43.
}

barracks from the first, Trajanic phase of the fort. For all that the authors dated the tile-stamp in Trajan-Hadrian time, probably thinking to a period before the organizing of the province Dacia Porolissensis and considered it is recording cohors I Ituraeorum sagittariorum. A tile-stamp of the same type CHSI 2 (Fig. 3) and probably pressed with the same stamp was discovered by us in 2012 during the excavation in the so-called "B6" building in the praetentura dextra of the Roman fort at Porolissum. I. Piso and D. Deac published it, but without the drawing and mentioning only "trouvée le 21 août 2012 par C. H. Opreanu dans l'édifice du camp de Pomet (Porolissum) entre la porta praetoria et le premier bastion est" ${ }^{25}$. Their data concerning the place of discovery are irrelevant, as they did not cite the interim report of the excavation ${ }^{26}$ with a detailed chronological frame of the building. The building was built up, roughly speaking, sometime between AD 140-160, belonging to the $1^{\text {st }}$ stone phase of the inner construction of the fort during Hadrian-Antoninus Pius time and it was in use till 180-190 AD. During the excavation from summer of 2019 in the praetorium building of the fort at Porolissum another fragment of a tile-stamp was recovered. It is of type CHS? (Fig. 4). The archaeological context was very precise and extremely significant. It belonged to building P2, room B, with an intact stratigraphy preserved. The tile stamp was found at $1.60 \mathrm{~m}$ deep in a first layer of destruction of the building belonging to the first stone phase. The building was renewed, probably in late $2^{\text {nd }}$ century, or at the beginning of the $3^{\text {rd }}$ century and under the topsoil a final ruin layer sealed the history of the building. That means is absolutely no doubt that the fragmentary tile-stamp was part of the tile roof of the first stone phase of the building P2. At Porolissum this phase was dated in Hadrian-Antoninus Pius period. The headquarters building was also done in Hadrian's time ${ }^{27}$. The authors of the recently excavated (2009-2011) water tank (former C3 building) succeeded to reconstruct the history of the building, two main construction phases being identified. The beginnings of its first stone phase was fortunately dated due to a small construction offering deposit that contained 3 coins, one from Vespasian and two from Antoninus Pius time (terminus post quem AD 148/149) ${ }^{28}$. The foundation inscription of the stone amphitheatre is from AD $157^{29}$. An inscription is mentioning a building part of the "customs point" which was "a solo restituit" because it was ruined by age ("vetustate dilapsum"). The action took place under Commodus (180-192), or under Septimius Severus (192197), or even under Caracalla (212-217) $)^{30}$. Obviously, the first stone building dated from Hadrian, at the latest from Antoninus Pius period. The same chronology for the stone phase was advanced also by the excavator of the "customs building", AD $135-160^{31}$. In conclusion there is solid archaeological evidence proving with no doubt that the tilestamps CHSI R, CHS ? from Porolissum and Romita and all the other types of the same unit were produced in Hadrian-

\footnotetext{
5 PISO/DEAC 2016, 246, LXV/2.

6 OPREANU/LĂZĂRESCU/ȘTEFAN 2013.

GUDEA/LANDES-GYEMANT 1983.

MUSTAŢĂ et alii 2014, 218; FIEDLER et alii 2018, 459.

29 CIL III 836.

PISO/OPREANU/DEAC 2016, 547.

1 GUDEA 1996, 49.
} 


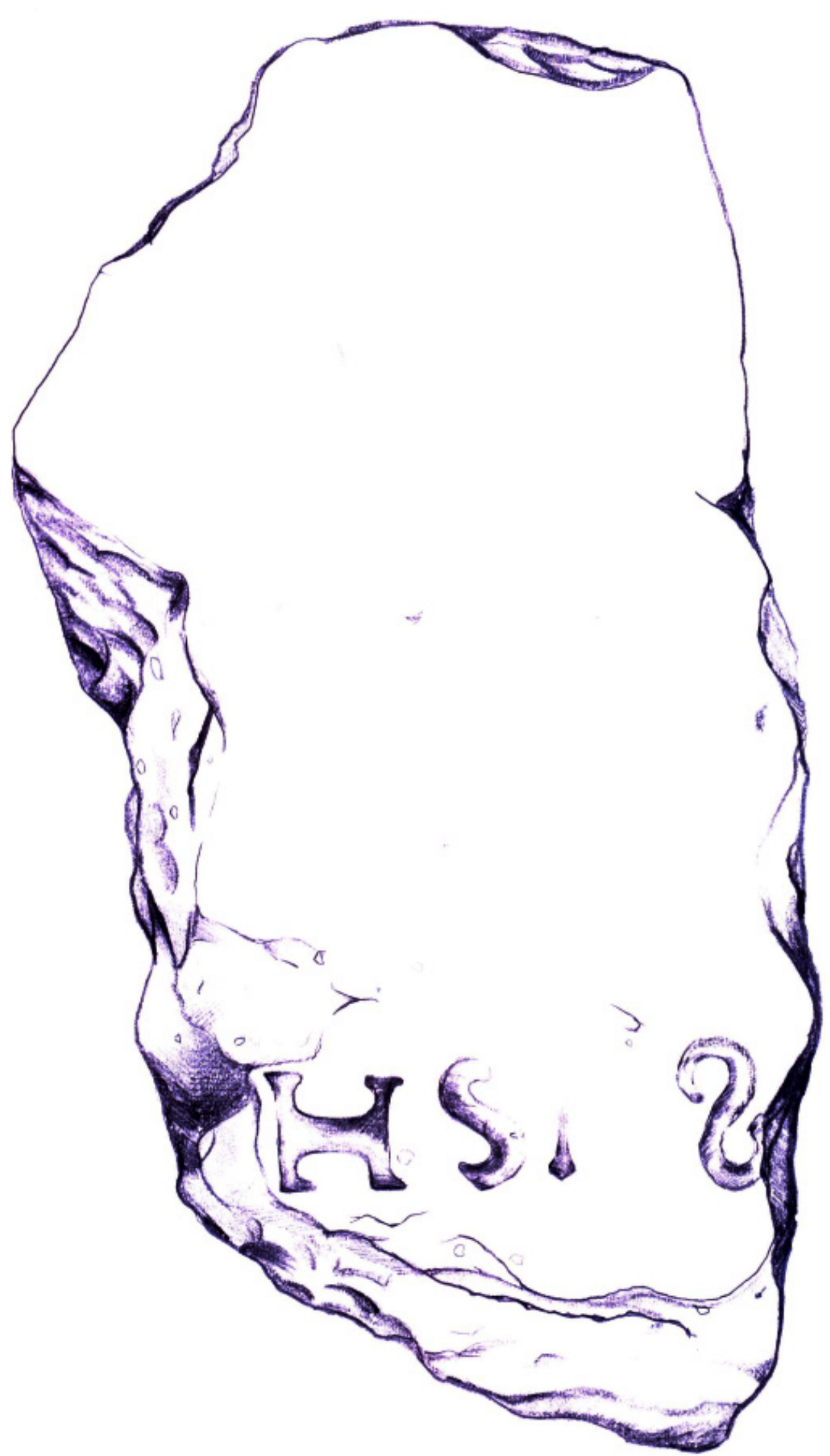

Fig. 3. Tile-stamp found in the ballistarium building ("B6") from the Roman fort at Porolissum in 2012 (unpublished). roofed with tiles.

Coming back to the identity of the unit which used these tile-stamps in the light of the chronology established on the archaeological context of the new researches at Romita and Porolissum we will analyze which of the candidate units are attested in Dacia for this period. First let's see the recent data on cohors I Ituraeorum sagittariorum. O. T,entea, the best specialist in the history of this unit and general in oriental auxiliary troops, recently followed the history of this cohort using the last epigraphical information available at the scale of the Roman Empire. He concluded that cohors I Ituraeorum milliaria participated to the Dacian War of Trajan and it stayed in the new province of Dacia, being recorded in the military diplomas from AD 109-110. Then it was taken with the expeditionary force in the Parthian War in $\mathrm{AD}$ 114 , the last year when it was attested in Dacia ${ }^{32}$. Later, in $\mathrm{AD} 135$ the unit returned (also from Orient) in its home province, Cappadocia ${ }^{33}$. Other two auxiliary troops having the ethnonym Ituraeorum are recorded exclusively in other provinces than Dacia ${ }^{34}$. In the light of this study it is obviously that cohors I Ituraeorum sagitariorum it is possible to work at Porolissum only between AD 106-114. But as we have seen, the tilestamps always used to prove its presence at Porolissum are from a later period. Recently it was published a circular bronze applique (tessera) with a punched inscription where can be read COH I ITVR. It was found in the 1990 excavation at the amphitheatre in a trench, at $0.50 \mathrm{~m}$ depth in the fill layers of the western entrance of the
Antoninus Pius, period when Porolissum and other forts were transformed in castra stativa and they were provided with stone defense walls, as well as with stone inner buildings

\footnotetext{
32 RMD IV, 226.

33 TENTEA/POPESCU 2016, 376-377.

34 ȚENTEA/POPESCU 2016, Table I.
} 
amphitheatre ${ }^{35}$. In absence of threshhold, the entrance was in fact a road. "Fill layers" means more layers resulted from the walking through the entrance and at the end from the ruin of the building. This is not a trusty archaeological context and is irrelevant for the chronology of the artifact. And another detail important for the moment when the artifact was lost in the entrance of the amphitheater: a second punched inscription more unmindful executed shows it had a second owner who lost it at a moment. Interesting is that the second owner does not seem to be a soldier, as he did not mention his unit and his direct officer in charge. In this situation what can we say about the mention of COH I ITVR? Tesserae are not decisive proofs for the presence of units in a fort. At Buciumi, for example, there are 3-4 units attested by tesserae from outside the fort's garrison ${ }^{36}$. One tessera means one soldier, or a group, possible in a mission outside its fort. But even if we accept that the applique from the amphitheater at Porolissum belonged to a soldier quartered with his unit at Porolissum the period when he and his unit was there cannot be other than early second century. In my opinion it only can be linked with the tile-stamps COH I AVG ${ }^{37}$. In conclusion, it is possible that an oriental unit recruited from the people of Ituraei to stayed in the area of Porolissum and Buciumi, but at AD 114 it left. From the moment of setting up the province of Dacia Porolissensis no trace of a permanent presence of a cohors Ituraeorum at Porolissum exists and the same is valid for the whole province. That means the tile-stamps in discussion must belong to a unit taken temporary from another province to Dacia Porolissensis. This situation is not unusual, as at Porolissum we have lots of tilestamps of troops from outside Dacia: COH III, LEG VII G F, LEG III G. They designed and built the inner building of the fort ${ }^{38}$. Among the tile-stamps of type CHSI २; CHS? with known place of discovery A. Rádnoti found 7 in the headquarters building of the fort at

35 DEAC 2018, 268.

${ }^{36}$ See, footnote 20.

37 The author of the note had real problems in finding the most "appropriate" chronology (DEAC 2018, 269-270). He wrote: "The unit was sent to the East during Trajan's Parthian campaigns, eventually returning to Cappadocia again, where it is recorded after 135 AD". Then reminding his professor's sureness: "At Porolissum the unit is attested only through a series of bricksstamps and graffiti made on roof tiles, dated to the Severan period" (PISO/ DEAC 2016, 240-248). Then panicked, mixed up the two contrary statements and sent them to ZPE: "Thus, it seems that the unit was based at Porolissum for a short while during the early years of Trajan's reign (although the concrete evidence is lacking at this stage) [our comment-except his present note], and definitely stationed in Porolissum sometime between 135 AD and the Severan period". (!) So, D. Deac succeeded to demonstrate how cohors I Ituraeorum was at the same time, after AD 135, at Porolissum (as Piso stated) and in Cappadocia (as military diploma recorded)!

38 See, OPREANU 2015.


Fig. 4. Tile-stamp found in the praetorium 2 building from the Roman fort at Porolissum in 2019 (unpublished).

Porolissum together with 107 pieces $\mathbf{C O H}$ III, 70 pieces LEG VII G F and 36 LEG III G ${ }^{39}$. In our excavation from B6 building ${ }^{40}$, even only few, the three type of tile- stamps found together are CHSI R; COH III; LEG VII G F. It is doubtless these are the units which built the inner buildings of the fort and not the permanent garrison composed of cohors I Ulpia Brittonum milliaria, cohors $V$ Lingonum $^{41}$ and very probably

\footnotetext{
39 OPREANU 2018, Table 1.

40 See, footnote 26.

${ }^{41}$ First time recorded in Dacia in AD 114 (RMD IV, 226).
} 
Numerus Palmyrenorum Porolissensium, which left very few tile-stamps compared with the units from outside. It's now time to try to find an identity to the unit which left the tilestamps CHSI 2; CHS2. When we discussed above the possible reading variants of the stamp, we reached the conclusion that it can be read as: cohors Sagittariorum I milliaria, or cohors Sagittariorum milliaria. Two auxiliary units with this name are recorded in the military diplomas. The first one is cohors I milliaria attested in the army of Syria in the diploma from $\mathrm{AD} 88^{42}$. It is not the same with cohors I milliaria sagittariorum from the army of Judea recorded in the military diplomas from $\mathrm{AD} 86^{43}$ and $\mathrm{AD} 90^{44}$. Little is known about this last unit. It seems it participated in $\mathrm{AD} 73$, or 74 to the siege of Masada ${ }^{45}$. What happened with it after AD 90 is unknown. Our hypothesis, expressed with maximum carefulness, so necessary to archaeological scientific research, is that this unit can be a candidate possible to be identified in the tilestamps at Porolissum, brought at a moment by Hadrian at Porolissum. As it did not let any official inscription at Porolissum it is sure it did not stay for a long period. A cohors I sagittariorum milliaria is also first time attested in garrison at Tibiscum in Upper Dacia in $\mathrm{AD} 165^{46}$. Whether is about the same unit, or not, is interesting that nothing is known concerning its history before AD $165^{47}$.

\section{REFERENCES}

CHIRILĂ et alii 1972

Chirilă, E./Gudea, N./Lucăcel, V./Pop, C., Castrul roman de la Buciumi. Contribuții la cercetarea limesului Daciei Porolissensis (Cluj).

COTTON/ECK/ISAAC 2003

Cotton, H.M./Eck, W./Isaac, B., A Newly Discovered Governor of Judeea in a military Diploma from $90 \mathrm{CE}$, Israel Museum Studies in Archaeology 2, 17-31.

DAICOVICIU 1941-1943

Daicoviciu, C., Asupra unor lucrări în legătură cu Dacia DEAC 2018 romană, Anuarul Institului de Studii Clasice 4, 282-320.

Deac, D., An Inscribed Bronze Applique (tessera militaris) from Porolissum (Roman Dacia), Zeitschrift für Papyrologie und Epigraphik 208, 268-272.

ECK 2010

Eck, W., A Second Constitution for the Auxiliary Troops in Judeea in 86 AD, Scripta Classica Israelica 9, 21-31.

ECK/WEIß 2009

Eck, W./Weiß, P. Eine Konstitution für die Truppen Iudaeas aus dem Jahr 87, Zeitschrift für Papyrologie und Epigraphik 120, 201-206.

FIEDLER et alii 2018

Fiedler, M./Höpken, K./Pánczél, S.-P./Bajusz, I./Döhner, G./Lenkey, L./Merzenich, C./Pethe, M./Vasáros, Z., Porolissum. Forschungen im Kastell auf dem Pomet von 2009 bis 2011. In: K. Müller, K./Schiller B., und der Fachschaftsrat des Winckelmann-Instituts der Humboldt - Universität zu Berlin (eds.), Von Kreta nach Kuba. Gedenkschrift zu Ehren des Berliner Archäaologen Veit Stürmer (Berlin: Logos), 449-468.

\footnotetext{
${ }^{42}$ ECK/WEIß 2009, 205.

${ }^{43}$ ECK 2010, 27.

${ }^{44}$ COTTON/ECK/ISAAC 2003, 25.

${ }_{45}$ ECK 2010, 27.

46 ȚENTEA 2012, 60-63.

${ }^{47}$ PETOLESCU 2002, 120-121, nr. 55.
}

GUDEA 1989

Gudea, N., Porolissum. Un complex arheologic daco-roman la marginea de nord a Imperiului Roman [=Acta Musei Porolissensis 13] (Zalău: Muzeul Judetean de Istorie și Artă)

GUDEA 1996

Gudea, N., Porolissum. Un complex arheologic daco-roman la marginea de nord a Imperiului Roman II. Vama romană. Monografie arheologică (Cluj-Napoca: Muzeul Judetean de Istorie și Artă).

\section{GUDEA 1997}

Gudea, N., Das Römergrenzkastell von Buciumi/ Castrul roman de la Buciumi (Zalău: Elcond)

\section{GUDEA/LANDES-GYEMANT 1983}

Gudea, N./Landes-Gyemant, A., Propuneri pentru o reconstituire grafică a castrului roman de pe Pomăt (Porolissum). I. Clădirea comandamentului, Acta Musei Porolissensis 7, 159-179.

MUSTAȚĂ et alii 2014

Mustață, S./Pánczel, S.-P./Petruț, D./Sidó, K., Drinking and gaming in the Roman fort of Porolissum. Preliminary data offered by the excavation at building C3, Studia Universitatis Babeș-Bolyai. Historia 59/1, 215-238.

\section{OPREANU 2015}

Opreanu, C.H., A Detachment of legio VII Gemina at Porolissum. When and Why?, Dacia N. S. 59, 299-309.

\section{OPREANU 2018}

Opreanu, C.H., The Garrison of the Roman Fort at Porolissum (Dacia). The Analysis of the Tile-Stamps, Open Archaeology 4, 365-372.

\section{OPREANU/LĂZĂRESCU/ȘTEFAN 2013}

Opreanu, C.H./Lăzărescu, V.-A./Ștefan, D., Noi cercetări la Porolissum, Analele Banatului 21, 83-106.

\section{PETOLESCU 2002}

Petolescu, C.C., Auxilia Daciae. Contribuții la istoria militară a PISO 2016 Daciei (București: Ars docendi)

Piso, I., Die rätselhafte Cohors I Augusta aus der Dacia Porolissensis. In: Ardevan, R./Beu-Dachin, E. (eds.), Mensa rotunda epigraphica Napocensis (Cluj-Napoca: Mega Publishing House), 35-46.

PISO 2018

Piso, I., Das verhängnisvolle Jahr 262 und die amissio Daciae. In: Vagalinski, L./Raycheva, M./Boteva, D./Sharankov, N. (eds.), Proceedings of the First International Roman and Late Antique Thrace Conference "Cities, Territories and Identities" (Plovdiv $3^{\text {rd }}-7^{\text {th }}$ October 2016) [Bulletin of the National Archaeological Institute 44] (Sofia: Bulgarian Academy of Sciences), 427-440.

\section{PISO/DEAC 2016}

Piso, I./Deac, D., Inscriptiones Daciae romanae. Appendix I Inscriptiones laterum Musei Zilahensis (Cluj-Napoca: Mega Publishing House).

PISO/MARCU 2016

Piso, I./Marcu, F., Inscriptiones Daciae romanae. Appendix II Inscriptiones laterum Musei Napocensis (Cluj-Napoca: Mega Publishing House).

PISO/OPREANU/DEAC 2016

Piso, I./Opreanu, C.H./Deac, D., Das Heiligtum der Zollstation von Porolissum, Zeitschrift für Papyrologie und Epigraphik 200, 544-548.

\section{SZILÁGYI 1946}

Szilágyi, J., A Dáciai erödrenszer helyörségei és a katonai téglabélyegek / Die Besatzungen des Verteidungssystems von Dazien und Ihre Ziegelstempel, Dissertationes Pannonicae II.21 (Budapest: A Pázmány Péter Tudományegyetem 
Érem- és Régiségtani Intézete).

TÓTH 1978

Tóth, E., Porolissum. Das Castellum in Moigrad. Ausgrabungen von A. Radnóti, 1943 (Budapest: Magyar Nemzeti Múzeum).

T,ENTEA 2004

Țentea, O., Cohors I Ituraeorum sagittariorum equitata milliaria, In: Ruscu, L./Ciongradi, C./Ardevan, R./Roman, C./Găzdac, C. (eds.), Orbis antiquus. Studia in honorem Ioannis Pisonis (Cluj-Napoca: Nereamia Napocae), 806815 .

\section{T,ENTEA 2012}

T,entea, O., Ex Oriente ad Danubium. The Syrian Units on the Danube Frontier of the Roman Empire (Cluj-Napoca: Mega Publishing House).

ȚENTEA/POPESCU 2016

Tientea, O./Matei-Popescu, F., The cohors I milliaria Ituraeorum. New Approach to its Deployment. In: Slavova, M./Šarankov, N./Michajlov, G.I. (eds.), Monuments and Texts in Antiquity and Beyond. Essays for the Centenary of Georgi Mihailov (1915-1991) [Studia Classica Serdicensia V] (Sofia: St. Kliment Ohridski University Press), 371-381. 